\title{
Comparing the Analysis and Results of a Modified Social Accounting Matrix Framework with Conventional Methods of Reporting Indirect Non-Medical Costs
}

\author{
Baudouin Standaert ${ }^{1}$ (D) Christophe Sauboin ${ }^{2,3}$ (D) $\cdot$ Quentin J. Leclerc ${ }^{4}$ (D) Mark P. Connolly ${ }^{5}$ (D)
}

Accepted: 31 October 2020 / Published online: 25 November 2020

(c) The Author(s) 2020

\begin{abstract}
Background Assessing the societal perspective in economic evaluations of new interventions requires estimates of indirect non-medical costs caused by the disease. Different methods exist for measuring the labor input function as a surrogate for these costs. They rarely specify the effect of health on labor and who gains and who loses money. Social accounting matrix (SAM) is an established framework that evaluates public policies with multiple perspectives that could help.

Objectives We evaluated the use of a modified SAM to assess money flows between different economic agents resulting in economic transactions following policy changes of medical interventions.

Methods We compared conventional methods of measuring indirect non-medical costs related to rotavirus vaccination in the Netherlands with a modified SAM framework. To compare the outcome of each method, we calculated returns on investment (ROI) as the net amount of money per euro invested in the vaccine. One-way and probabilistic sensitivity analyses were carried out for each method, focusing on critical variables with the largest impact on indirect cost estimates.

Results The ROI was higher for the modified SAM (1.33) than for the conventional methods assessing income calculations (range -0.178 to 1.22 ). Probabilistic sensitivity analyses showed wide distributions in the ROI estimates, with variation in the variable impact on the indirect cost results per method selected.

Conclusions In contrast to conventional methods, the SAM approach provides detailed and comprehensive assessments of the impact of new interventions on the indirect non-medical costs and the financial interactions between agents, disclosing useful information for different stakeholders.
\end{abstract}

Baudouin Standaert

baudouin.standaert@skynet.be

Christophe Sauboin

csauboin@yahoo.fr

Quentin J. Leclerc

Quentin.Leclerc@1shtm.ac.uk

Mark P. Connolly

mark@gmasoln.com

1 HEBO bv, Antwerpen, Belgium

2 The University Medical Center Groningen, Groningen, The Netherlands

3 Boehringer Ingelheim, Global Market Access Excellence, Ingelheim am Rhein, Germany

4 Department of Infectious Disease Epidemiology, Faculty of Epidemiology and Population Health, London School of Hygiene and Tropical Medicine, London, UK

5 Unit of Pharmacoepidemiology and Pharmacoeconomics, Department of Pharmacy, University of Groningen, Groningen, The Netherlands

\section{Introduction}

Health economic evaluations of new medical products are normally performed through incremental cost effectiveness analysis (CEA) using direct medical costs from a healthcare perspective [1-4]. Some countries recommend a societal perspective, especially when new technologies may have an impact on the economy outside healthcare [5-8]. Evaluating health economics from a societal perspective has until recently been poorly developed. New attempts have been made to explore what could be more appropriate when different stakeholders with different value settings assess the benefit of a new intervention looking for the impact at the individual- or dimension-specific level [9]. These are interesting explorations, but much effort may be required before a consensus is reached in the evaluation. This process needs to be repeated for every country assessment, as many of the value considerations are culturally, and therefore locally, defined. Meanwhile, we aim to focus on one specific element 


\section{Key Points}

Several methods exist to calculate the changes in the labor input function attributable to poor health as a surrogate for indirect non-medical costs within a societal perspective of health economic assessment. However, conventional methods fail to capture information about who gains and who loses upon the change in labor input due to illness or a new intervention aimed at treating or preventing a disease.

Social Accounting Matrix (SAM) analyzes financial relationships between different economic agents and assesses the impact of a new intervention at all levels of the economy simultaneously (e.g., households, companies and government).

The analysis of rotavirus vaccination in the Netherlands with a modified SAM analysis shows who gets more or who gets less upon the introduction of the vaccination, adding valuable information for different stakeholders and decision makers.

that should be assessed in depth if the economic analysis is evaluated at the societal level, namely the indirect non-medical costs. It is maybe a narrow focus in the health economic assessment overall, but for some diseases and under some circumstances this item could be important to scrutinize from the perspective of the different stakeholders involved. Indirect non-medical costs are here defined as changes in the labor input function caused by work reduction or interruption due to a disease [10-12]. These costs can be evaluated from an individual, an employer and/or a governmental perspective. As there is no single recommended approach, large variations in indirect non-medical cost estimates are reported $[13,14]$. In addition, contemporary methods used to assess that item often lack the ability to consider more than one perspective simultaneously and to describe the money flows that occur between economic domains following the introduction of a medical intervention, such as the impact of a reduction in household income on tax revenues. This lack of completeness when evaluating indirect nonmedical costs renders societal CEA evaluation results prone to criticism [15].

In public policy there exists an analytical framework that can overcome these hurdles, providing multiple perspectives into one analysis and helping understand the money flows across different economic agents, the social accounting matrix (SAM) $[16,17]$. SAMs have been widely used in financial econometrics to understand transactions and transfers between different economic agents, such as households, private firms, and governmental bodies, to monitor distribution of wealth and poverty at equilibrium $[16,18$, 19].

In this study, we evaluate the benefits of using a modified SAM framework focused on the distribution of income applicable to healthcare by comparing its results with the conventional methods applied to estimate indirect non-medical costs using the human capital method. We investigate rotavirus (RV) disease as an example to study the impact of vaccination in one specific country, the Netherlands, and variation attributed to different methods for assessing indirect costs [20-22]. To date, RV vaccination has not been implemented by the Dutch health authorities, although it is recommended by the World Health Organization, and it is in place in several European countries, including Belgium, Germany, and the UK [23]. The modified SAM methodology may thereby provide policymakers (Ministry of Health $[\mathrm{MoH}]$ and of Finance $[\mathrm{MoF}])$ a better understanding of the effects a new intervention has on money flows that build up to changes in indirect non-medical costs.

\section{Methods}

\subsection{Population and Epidemiology Data Describing Rotavirus Disease and the Interventions}

$\mathrm{RV}$ infection is the main cause of diarrheal disease in young children and infects almost every child before the age of 5 years. Several vaccines exist with comparable vaccine efficacy. Only two are available in Europe, a two-dose vaccine, Rotarix (GlaxoSmithKline, Belgium) and a three-dose vaccine, Rotateq (Merck and Co. Inc) [24]. Both vaccines are administered within the first 6 months of age $[25,26]$. Demographic and epidemiological data have been sourced from official Dutch statistics and published literature as described elsewhere [22] (Table 1). The number of individuals at risk of infection includes children aged $0-5$ years old. Most children with RV infection, on average $40 \%$ per year, recover at home. However, $13 \%$ of RV events lead to a general practitioner (GP) visit, $1.6 \%$ require hospitalization, and $0.4 \%$ lead to nosocomial infection [27]. These numbers are based on an economic model for RV vaccine in the Netherlands [22]. Inclusion of the RV vaccine into the universal mass vaccination (UMV) program would reduce the rotavirus disease incidence in children by approximately $65 \%$ [27].

\subsection{Direct Medical Costs}

In our economic models, direct medical costs include medical visits, hospitalization, nosocomial infections, and vaccine costs. In the case of RV UMV, a vaccination coverage of $90 \%$ and a tender reduction on vaccine costs of $5 \%$ were assumed [27] (Table 1). 


\subsection{Indirect Non-Medical Costs}

Indirect non-medical costs are estimated using the conventional methods and the application of a modified SAM method. The methods have the same assumptions for vaccine coverage, vaccine efficacy, and days off work due to illness.

Indirect non-medical costs relate to labor input because parents caring for children with RV are absent from work. A reduction in labor time because of disease that forces people to stay at home to care for children may lead to a reduction in production for firms [8]. We briefly summarize how the labor input function is estimated by the conventional methods, each utilizing a slightly different calculation method. We then describe how that is captured by a modified SAM framework.

\subsubsection{Conventional Methods}

We consider three calculation methods for the conventional approach for estimating the change in labor input function in the Netherlands. The most commonly used method for the estimation relies on gross income, corresponding to the classic human capital approach $[28,29]$. The argument supporting the choice of gross wages as a marker of labor input is that the amount of money given to individuals corresponds to the direct compensation for their contribution to the overall production.

Alternatively, net income may be used instead of gross income [30]. It is an extension of the previous estimate, where individuals' net income is their return on labor input. The net income corresponds to the money received after deduction of income tax and/or contribution to social security.

The adjusted gross income (AGI) accounts for the specifics of the Dutch social security system, where employed individuals are still paid $70 \%$ of their wages when off work to care for a sick family member [31]. We therefore consider that employed individuals only lose $30 \%$ of their daily gross income for each day spent off work taking care of a sick child. Independent contractors, on the other hand, lose $100 \%$ of their daily gross income [32].

Table 2 summarizes how these data are calculated with the input variables (Table 1).

\subsubsection{Modified SAM Framework}

SAMs are normally used to assess the effect of policies or interventions on the overall economy by establishing links between the labor market (households) and financial, economic, and social policies [33]. The original SAM uses a comprehensive and economy-wide database recording data on transactions between economic agents of a certain economy like agriculture or industry. The interest in working with
SAMs is twofold: it provides data for economic modelling (multi-sectorial linear models or the more complex Computable General Equilibrium [CGE] models) and it shows a complete but intuitive snapshot of the economy at hand. The concept of using SAMs started with Stone [34]; his pioneering work on social accounting includes conventions that have been used by economic and statistical organizations. Pyatt and Thorbecke [35] later formalized the concept of the SAM and facilitated its use as an economic analysis and planning framework. Underlying is the circular flow of income, a concept going back to the circular economy proposed by Boulding [36].

The modified SAM framework developed here focuses on the distribution of income in vaccinated and unvaccinated cohorts and the spending of those likely to be impacted by a disease [37]. It explores how RV vaccination of birth cohorts in the Netherlands influences the money flows during a timeframe of 1 year. It results in more complete indirect cost estimates with money transfers between the different economic agents impacted by the RV disease, the consequences on labor force input and on production. We considered the following economic stakeholders: households, firms, MoF, $\mathrm{MoH}$, health insurance companies (HiC), and vaccine manufacturers. Our starting point to select a stakeholder was the household being exposed to rotavirus diarrhea in children. The working parent is affected by the money received and spent. The analysis highlights which other stakeholders are impacted when the parent receives or spends money. Selected stakeholders are related to the money changing hands. The sum of money spent must be equal to the sum of money received in this closed system.

Each economic agent appears in both the columns and rows of a square matrix as reported in Tables 4 and 5 describing part of the modified SAM approach. Money transfer between two agents is displayed in the corresponding cell. For example, the adjusted gross income paid by firms to their employees (households) appears under the column 'firms' and the row 'households'. The sum over each row represents the revenue of the corresponding economic agent, while the sum over columns corresponds to their expenses. We created two modified SAMs representing the money flows with and without RV vaccination, respectively. The difference between the two matrices captures to what extent the investment in disease prevention generates a benefit to the economy as a whole and per stakeholder type. Table 2B gives the equations used to plug in the numbers in the matrix calculation presented in the results using the input data listed in Table 1.

\subsection{Analysis}

A decision tree disease and management model has been developed and is described in detail elsewhere [22]. The 
Table 1 Epidemiology and other input data [22]

\begin{tabular}{|c|c|c|c|c|}
\hline Parameter & Code & Input value & Source & Reference \\
\hline Annual birth cohort & Annual_birth_cohort & 182,283 & Goossens et al., 2008 & {$[27]$} \\
\hline Total annual RV events ${ }^{\mathrm{a}}$ & Total_RV_events & $73,456(40 \%)^{\mathrm{a}}$ & Goossens et al., 2008 & [27] \\
\hline Staying home & Cases_home & $45,365(25 \%)^{\mathrm{a}}$ & Goossens et al., 2008 & [27] \\
\hline Medical visit & Cases_GP & $24,343(13 \%)^{\mathrm{a}}$ & Goossens et al., 2008 & [27] \\
\hline Hospital & Cases_hosp & $2940(1.6 \%)^{\mathrm{a}}$ & Goossens et al., 2008 & {$[27]$} \\
\hline Nosocomial & Cases_nos & $808(0.4 \%)^{\mathrm{a}}$ & Goossens et al., 2008 & [27] \\
\hline Vaccine effect overall & VE_overall & $65 \%$ & Zorginstituut, 2017 & [46] \\
\hline 1-Vaccine effect - medical visit & VE_MedV & $12 \%$ & Goossens et al., 2008 & [27] \\
\hline 1-Vaccine effect - hospitalization & VE_Hosp & $7 \%$ & & \\
\hline 1-Vaccine effect - nosocomial & VE_Noso & $22 \%$ & & \\
\hline Average days being absent from work & Labor_input & 5.5 days & Calculated & \\
\hline \multicolumn{5}{|l|}{ Direct medical costs } \\
\hline Cost - GP visit & Cost_GP & $€ 31.8$ & Kotsopoulos et al., 2019 & {$[22]$} \\
\hline Cost - hospitalization & Cost_hosp & $€ 2482$ & Kotsopoulos et al., 2019 & {$[22]$} \\
\hline Cost - nosocomial infection & Cost_nos & $€ 2253$ & Kotsopoulos et al., 2019 & {$[22]$} \\
\hline Vaccine cost/course & Vaccine_cost & $€ 117$ & Kotsopoulos et al., 2019 & {$[22]$} \\
\hline Vaccine coverage & Vac_cov & $90 \%$ & Assumption & \\
\hline Tender reduction cost & Tender_add & $5 \%$ & Assumption & \\
\hline \multicolumn{5}{|l|}{ Indirect non-medical costs } \\
\hline $\begin{array}{l}\text { Gross earnings of an employed } 25 \text { - to } \\
35 \text {-year-old } \mathrm{m} / \mathrm{f}\end{array}$ & Gross_earnings_employed & $€ 33,900$ & $\begin{array}{c}\text { Central Bureau of Statistics } 2018 \\
\text { (Werkzame Beroepsbevolking) }\end{array}$ & [47] \\
\hline $\begin{array}{l}\text { Gross earnings of an independent } \\
\text { contractor } \\
25 \text { - to } 35 \text {-year-old } \mathrm{m} / \mathrm{f}\end{array}$ & Gross_earnings_independent & $€ 32,000$ & $\begin{array}{r}\text { Central Bureau of Statistics } 2018 \\
\text { (Werkzame Beroepsbevolking) }\end{array}$ & [47] \\
\hline $\begin{array}{l}\text { Proportion of employed workers } 25 \text { - } \\
\text { to } 35 \text {-year-old } \mathrm{m} / \mathrm{f}\end{array}$ & Prop_employed & $88 \%$ & $\begin{array}{r}\text { Central Bureau of Statistics } 2018 \\
\text { (Werkzame Beroepsbevolking) }\end{array}$ & [47] \\
\hline $\begin{array}{l}\text { Proportion of independent contract } \\
\text { workers } \\
25 \text { - to } 35 \text {-year-old } \mathrm{m} / \mathrm{f}\end{array}$ & Prop_independent & $12 \%$ & $\begin{array}{r}\text { Central Bureau of Statistics } 2018 \\
\text { (Werkzame Beroepsbevolking) }\end{array}$ & [47] \\
\hline Income tax rate & Income_tax_rate & $40.85 \%$ & $\begin{array}{l}\text { Belastingdienst } 2018 \text { (Inkomstenbelast- } \\
\text { ing) }\end{array}$ & [48] \\
\hline $\begin{array}{l}\text { Reimbursement employed for absen- } \\
\text { teeism of care }\end{array}$ & Reimb_employed & $70 \%$ & Rijksoverheid 2018 & [49] \\
\hline $\begin{array}{l}\text { Gross disposable income main bread- } \\
\text { winner }<35 \text { years }\end{array}$ & Disposable_income & $75 \%$ & $\begin{array}{l}\text { Central Bureau of Statistics } 2018 \text { (Inko- } \\
\text { mensverdeling) }\end{array}$ & {$[50]$} \\
\hline VAT on G\&S & VAT_rate & $21 \%$ & OECD 2016 & {$[51]$} \\
\hline Annual working days & Working_days & 232 & Calculated (Kotsopoulos et al., 2019) & {$[22]$} \\
\hline $\begin{array}{l}\text { Average payment household insur- } \\
\text { ance/year }\end{array}$ & Insurance_fee & $€ 1200$ & Kotsopoulos et al., 2019 & {$[22]$} \\
\hline \multicolumn{5}{|l|}{ Firms } \\
\hline Gross profit before taxes & Firm_profit & $€ 222,097,000,000$ & $\begin{array}{l}\text { Central Bureau of Statistics } 2016 \\
\text { (national accounts) }\end{array}$ & {$[52]$} \\
\hline Total workforce & Total_workforce & $6,526,000$ & $\begin{array}{l}\text { Central Bureau of Statistics } 2016 \\
\text { (national accounts) }\end{array}$ & {$[52]$} \\
\hline Annual profitability per employee & Firm_profit/Total_workforce & $€ 34,033$ & Kotsopoulos et al., 2019 & {$[22]$} \\
\hline Corporate tax rate & Corporate_tax_rate & $20 \%$ & Belastingdienst 2018 (Winst) & {$[53]$} \\
\hline
\end{tabular}

$G \& S$ goods and services, $G P$ general practitioner, $m / f$ male/female, $O E C D$ Organisation for Economic Co-operation and Development, $R V$ rotavirus, VAT value-added tax

${ }^{a}$ Numbers in brackets indicate values when the vaccine is used 
Table 2 Equations to calculate the indirect cost estimates using the conventional methods (A) and the modified SAM model (B)

Definition Formula

\section{Cost per event (input in Table 4)}

Conventional method A

Direct medical cost/event

Average indirect gross income loss/event

Average indirect adjusted gross income loss/event

Average indirect net income loss/event

SAM model B (no vaccine)

Average money loss Household-Firms per event

Average money loss Firms-Household per event

Average money loss MoF-Household per event

Average money loss MoF-Firms per event Average money loss $\mathrm{MoH}-\mathrm{HiC}$ per event

The difference (input in Table 5)

\section{Conventional method A}

Medical cost (MC)

No vaccine ${ }_{M C}$

Adjusted cases GP (example)

$\mathrm{UMV}_{\mathrm{MC}}$

Cost-savings $_{\mathrm{MC}}$

Gross income (GI)

Total_RV_events

Total_adjusted_RV_events

Total_vaccine_cost

No vaccine GI $_{\text {I }}$

$\mathrm{UMV}_{\mathrm{GI}}$

Cost-savings $_{\mathrm{GI}}$

Total cost-offset ${ }_{\mathrm{GI}}$

Net savings ${ }_{\mathrm{GI}}$

$\mathrm{ROI}_{\mathrm{GI}}$

SAM method B (savings between Vaccine/No Vaccine)

Net earnings
(Cases_GP*Cost_GP + Cases_hosp*Cost_hosp + Cases_nos*Cost_nos) $/($ Cases_ GP + Cases_hosp + Cases_nos)

$((1-$ Reimb_employed $) *$ Gross_earnings_employed $*($ labor_input/working_days $)) /(1-$ Reimb_employed) *Prop_employed+Gross_earnings_independent* (labor_input/ working_days) *Prop_independent

(1-Reimb_employed) *Gross_earnings_employed *(labor_input/working_days) *Prop_ employed+Gross_earnings_independent* (labor_input/working_days) *Prop_independent

((1-Reimb_employed) *Gross_earnings_employed *(labor_input/working_days)

*Prop_employed + Gross_earnings_independent* (labor_input/working_days)

*Prop_independent)*(1-Income_tax_rate)

(1-Reimb_employed) *Gross_earnings_employed *(labor_input/working_days) *Prop_ employed+Gross_earnings_independent* (labor_input/working_days) *Prop_independent

$\left(\left(\left(1-R e i m b \_\right.\right.\right.$employed $) *$ Gross_earnings_employed *(labor_input/working_days)

*Prop_employed + Gross_earnings_independent* (labor_input/working_days)

*Prop_independent)* (1-Income_tax_rate) $)^{*}$ disposable income

((1-Reimb_employed) $*$ Gross_earnings_employed *(labor_input/working_days) *Income_tax_rate $+(1-$ Reimb_employed $) *$ Gross_earnings_employed $*($ labor_ input/working_days) (1-Income_tax_rate) *Disposable_income* VAT_rate) *Prop_employed + ((Gross_earnings_independent* (labor_input/working_days) *Income_tax_rate+Gross_earnings_independent* (labor_input/working_days)*(1Income_tax_rate) *Disposable_income* VAT_rate) )*Prop_independent

Daily_profitability_per_employee* labor_input* corporate_tax_rate

(Cases_GP*Cost_GP + Cases_hosp*Cost_hosp + Cases_nos*Cost_nos) $/($ Cases_ GP + Cases_hosp + Cases_nos)

Cases_GP*Cost_GP + Cases_hosp*Cost_hosp + Cases_nos*Cost_nos

Cases_GP *Vac_cov*VE_MedV + Cases_GP*(1-Vac_cov)

Adjusted_cases_GP*Cost_GP+Adjusted_cases_hosp*Cost_hosp + Adjusted_cases_ nos*Cost_nos

No vaccine MC $-\mathrm{UMV}_{\mathrm{MC}}$

Cases_home + Cases_GP + Cases_hosp + Cases_nos

Total_RV_events*(Vac_cov*(1-VE_overall $\left.)+\left(1-V a c \_c o v\right)\right)$

Annual_birth_cohort* Vac_cov* Vaccine_cost

Total_RV_events* average indirect gross income loss/event

Total_adjusted_RV_events* average indirect gross income loss/event

No vaccine $_{\mathrm{GI}}-\mathrm{UMV}_{\mathrm{GI}}$

Cost-savings $\mathrm{GI}_{\mathrm{GI}}+$ Cost-savings $\mathrm{MC}_{\mathrm{MC}}$

Total cost-offset ${ }_{\mathrm{GI}}$ - Total_vaccine_cost

Net savings ${ }_{\mathrm{GI}} /$ Total_vaccine_cost

$((1-$ Income_tax_rate $) *$ Gross_earnings_employed $) *$ Prop_employed $+((1$-Income_tax rate) *Gross_earnings_independent)* Prop_independent 
Table 2 (continued)

\begin{tabular}{|c|c|}
\hline Definition & Formula \\
\hline Rota_adjusted_net earnings & $\begin{array}{l}(((1-\text { Income_tax_rate }) * \text { Gross_earnings_employed) }-((1-\text { Income_tax_rate }) * \\
\text { Gross_earnings_employed)*(labor_input/Working_days)* AC)* Prop_ } \\
\text { employed }+(((1-\text { Income_tax_rate }) * \text { Gross_earnings_independent })-(1-\text { Income_tax_- } \\
\text { rate }) * \text { Gross_earnings_independent* (labor_input/Working_days })) * \text { Prop_independ- } \\
\text { ent }\end{array}$ \\
\hline Household-Firms & No_vaccine $_{\text {AGI }}-\mathrm{UMV}_{\mathrm{AGI}}$ \\
\hline Firms-Household & $\begin{array}{l}\text { [(((Annual_birth_cohort-Total_RV_events)* Net_earnings) +(Total_RV_events } \\
\text { *Rota_adjusted_net_earnings) }) * \text { Disposable_income] - [((Annual_birth_cohort- } \\
\text { Total_adjusted_RV_events) *Net_earnings })+(\text { Total_adjusted_RV_events *Rota_ } \\
\text { adjusted_net_earnings })) * \text { Disposable_income] }\end{array}$ \\
\hline Loss of income tax/RV case $_{\mathrm{E}}$ & AC*Gross_earnings_employed*(labor_input/Working_days) *(Income_tax_rate) \\
\hline Loss of VAT tax/RV case $_{\mathrm{E}}$ & $\begin{array}{l}\text { AC*Gross_earnings_employed*(labor_input/Working_days) *(1-Income_tax_rate) } \\
\text { *Disposable_income*VAT_rate }\end{array}$ \\
\hline Total tax $\operatorname{loss}_{\mathrm{E}}$ & Loss of income Tax/RV case $e_{\mathrm{E}}+$ Loss of VAT tax/RV case $\mathrm{E}_{\mathrm{E}}$ \\
\hline MoF-Household & $\begin{array}{l}\text { [Annual_birth_cohort*((Income_tax_rate*Gross_earnings) }+(\text { Net_ } \\
\text { earnings*Disposable_income*VAT_rate }))-(\text { Total_RV_events*Total tax } \\
\text { loss }{ }_{E}^{*} \text { Prop_employed +Total_RV_events*Total tax lossI*Prop_independ- } \\
\text { ent)]- [Annual_birth_cohort*((Income_tax_rate*Gross_earnings })+(\text { Net_- } \\
\text { earnings*Disposable_income*VAT_rate }))-(\text { Total_adjusted_RV_events*Total tax } \\
\text { loss }{ }_{\text {E }}^{*} \text { Prop_employed +Total_adjusted_RV_events*Total tax loss }{ }^{*} \text { Prop_independ- } \\
\text { ent)] }\end{array}$ \\
\hline MoF-Firms & $\begin{array}{l}\text { [((Annual_birth_cohort* Annual_profitability_per_employee)-(Daily_profitabil- } \\
\text { ity_per_employee *labor_input*Total_RV_events)) *Corporate_tax_rate]-[((Total_ } \\
\text { households* Annual_profitability_per_employee)-(Daily_profitability_per_employee } \\
\text { *labor_input *Total_adjusted_RV_events)) *Corporate_tax_rate] }\end{array}$ \\
\hline MoF-Vaccine producer & Total_vaccine_cost* Tender add \\
\hline $\mathrm{MoH}-\mathrm{HiC}$ & No vaccine $_{M C}-\mathrm{UMV}_{\mathrm{MC}}$ \\
\hline HiC-Household & Insurance_fee*Annual_birth_cohort-Insurance fee*Annual_birth_cohort \\
\hline Vaccine producer-MoH & Total_vaccine_cost \\
\hline Revenue/Expenditures & $\begin{array}{l}\text { Sum (Household-Firms; Firms-Household; MoF-Household; MoF-Firms; MoF-Vac- } \\
\text { cine producer; MoH-HiC; HiC-Household; Vaccine producer- MoH) }\end{array}$ \\
\hline Net savings & Revenue- Total_vaccine cost \\
\hline ROI & Net_savings/Total_vaccine_cost \\
\hline
\end{tabular}

All other abbreviations used in the second column are defined in Table 1 (second column) or in Table 2 (first column)

$A G I$ adjusted gross income, $E$ employed, $G P$ general practitioner, $H i C$ healthcare insurance companies, hosp hospitalization, $I$ independent, $M o F$ Ministry of Finance, $M o H$ Ministry of Health, nos nosocomial, prop proportion, ROI return on investment, $R V$ rotavirus, $S A M$ social accounting matrix, $U M V$ universal mass vaccination, VAT value-added tax

model is used to assess indirect non-medical costs as a proxy for changes in labor input using the different approaches described above with a time horizon of 1 year at infection equilibrium time. All input parameters and calculation methods are provided in Table 1 and 2. In a first step, each conventional method is compared with the SAM method in terms of average indirect non-medical cost per RV event with no vaccination. To this aim, four perspectives were combined in the SAM model, namely households, firms, $\mathrm{MoH}$, and the HiC. These are closely interrelated in the evaluation of labor input and production. In a second step, the overall impact of vaccination on annual direct and indirect non-medical costs are calculated as the difference between total costs with and without vaccination, assuming a new steady state of infections has been reached. The results of the conventional approaches are compared with the SAM-model output, which includes in addition the MoF and the vaccine manufacturer among the stakeholders.

Finally, we measured the return on investment (ROI) corresponding to the ratio of the net amount of money per euro invested in the vaccine [38]. An ROI of 0 indicates that the intervention is cost-neutral; a positive ROI shows that money is saved, while a negative ROI means that part of the invested money is lost.

\subsection{Sensitivity Analyses}

Indirect cost estimates are derived from different variables whose values are associated with uncertainty. To assess the robustness of our results, deterministic and probabilistic 
sensitivity analyses (PSA) are carried out. These analyses permit to identify parameters with the largest impact on the indirect non-medical costs and to visualize and compare the distribution of the estimates for each method using the ROI as a common measure of comparison. We know from our previous SAM analysis that 10 variables are critical in measuring the vaccine cost-offset and the economic surplus: (1) vaccine price, (2) vaccine coverage, (3) vaccine efficacy, (4) the proportion of workers fully employed, (5) number of days being absent from work, (6) total number of RV events, (7) corporate taxes, (8) reimbursement rate of employees, (9) disposable income, and (10) gross income [22]. The range of values and distributions used are shown in Table 3. They have been assembled based on a round table discussion with local experts in the Netherlands after the presentation of the previous analysis [22]. For the PSA, 5000 runs of MonteCarlo simulations were carried out using @ Risk software, Palisade 8, 2020.

\section{Results}

\subsection{Indirect Non-Medical Costs per RV Event}

Table 4 is split into two parts. The upper part reports the outcomes per conventional method used, while the lower part is the result of the SAM modeling exercise. The colored cells indicate where the conventional approach coincides with the SAM analysis framework, and should reflect the same result type.

Using conventional methods, the average indirect nonmedical cost per RV event varies depending on the selected method: the lowest estimate is obtained with the net income method (€181.09), while the highest is obtained with the gross wages (€806.04). When using the AGI estimation, the results lie in between the two extremes (€306.16). Direct medical costs, including treatment costs, GP visits, and hospitalization, are in the same order of magnitude as the indirect non-medical costs (€352.13).

In the modified SAM approach (lower part of Table 4), each component of the indirect non-medical cost is presented as a payment between two economic agents. Some of these money transfers exactly match those calculated with the conventional approaches: the indirect non-medical cost due to a wage decrease is shown as a monetary transaction from firms to households in the SAM matrix (same color code for those cells). It corresponds to the indirect non-medical cost estimate obtained with the adjusted gross income method. Other values deviate from those obtained with conventional methods due to the additional details provided in the modified SAM. For example, household spending is in general proportionate to income and thus both $\mathrm{MoF}$ and private firms will receive less money from households in case of work absenteeism. Within the SAM approach, the total indirect non-medical cost corresponds to the sum of revenue loss perceived by households, firms, and the $\mathrm{MoF}$ (€758.50), while direct medical costs amount to $€ 352.13$, as in the conventional methods.

\subsection{Total Disease Costs and Impact of Vaccination}

Total disease-related costs were estimated by multiplying costs per RV event by the total number of RV events. Vaccination reduces the number of events per year from 73,456 to 30,484 events (Table 1), leading to a reduction in direct medical costs of approximately 8 million euros (Table 5). The reduction in indirect non-medical costs varies depending on the method used, but indirect non-medical cost savings can be higher than the cost savings for direct medical costs (Table 5).

Table 5 also presents estimated changes in money flow upon RV UMV introduction using the modified SAM

Table 3 List of variables for which the probabilistic sensitivity analysis is performed

\begin{tabular}{lllll}
\hline & Variable & Code & Baseline value & Distribution value \\
\hline 1 & Total annual RV events $^{\mathrm{a}}$ & Total_RV_events & 73,456 & Normal $(73,456 ; 6250)$ \\
2 & $\begin{array}{l}\text { Proportion of employed workers 25- to 35-year-old } \\
\text { m/f }\end{array}$ & Prop_employed & $88 \%$ & Uniform $(88 \% ;-5 \% ;+5 \% ; 10$ steps) \\
3 & Vaccine cost/course & Vaccine_cost & $€ 117$ & Pert $(105.3 ; 117 ; 120)$ \\
4 & Vaccine effect overall & VE_overall & $(100-65 \%)$ & Normal $(35 \% ; 3.5 \%)$ \\
5 & Average days being absent from work & Labor_input & 5.5 days & Uniform $(5.5 ; 4.6 ; 6.05)$ \\
6 & Vaccine coverage & Vac_cov & $90 \%$ & Normal $(90 \% ; 4 \%)$ \\
7 & Gross earnings of an employed 25- to 35-year-old m/f & Gross_earnings_employed & $€ 33,900$ & Pert $(33,000 ; 33,900 ; 34,000)$ \\
8 & Reimbursement employed for absenteeism of care & Reimb_employed & $(100-70 \%)$ & Normal $(30 \% ; 3 \%)$ \\
9 & Gross disposable income main breadwinner <35 years & Disposable_income & $75 \%$ & Pert $(70 \% ; 75 \% ; 80 \%)$ \\
10 & Corporate tax rate & Corporate_tax_rate & $20 \%$ & Pert $(18 \% ; 20 \% ; 22 \%)$ \\
\hline
\end{tabular}

$m / f$ male/female, $R V$ rotavirus, $V a c \_c o v$ vaccination coverage, $V E$ vaccine efficacy 
Table 4 Average indirect non-medical cost per RV event using conventional methods and the modified SAM approach

\begin{tabular}{|c|c|c|c|c|c|c|}
\hline \multicolumn{7}{|c|}{ Conventional of Measuring Direct and Indirect Costs ${ }^{\mathrm{a}}$} \\
\hline Cost type & Direct & \multicolumn{5}{|c|}{ Indirect } \\
\hline Method & Medical cost & Gross income & \multicolumn{2}{|c|}{ Adjusted gross income } & \multicolumn{2}{|c|}{ Net income } \\
\hline & 1 & 2 & \multicolumn{2}{|c|}{3} & \multicolumn{2}{|c|}{4} \\
\hline Cost/Event (€) & 352.13 & 806.04 & \multicolumn{2}{|c|}{306.16} & \multicolumn{2}{|c|}{181.09} \\
\hline Comment & & & \multicolumn{2}{|c|}{$\begin{array}{l}30 \% \text { loss for the } 88 \% \text { employed } \\
100 \% \text { for independent workers }\end{array}$} & \multicolumn{2}{|c|}{$\begin{array}{l}\text { No adjustment to disposable } \\
\text { income of } 75 \%\end{array}$} \\
\hline \multicolumn{7}{|c|}{ Modified SAM Method of Measuring Direct and Indirect Costs (€) } \\
\hline & Households & Firms & MoF & МоH & HiC & Revenue \\
\hline Households & & 306.16 & & & & 306.16 \\
\hline Firms & 135.82 & & & & & 135.82 \\
\hline MoF & 153.59 & 162.94 & & & & 316.52 \\
\hline МoH & & & & & 352.13 & 352.13 \\
\hline \multicolumn{7}{|l|}{ HiC } \\
\hline Expenditure & 289.41 & 469.09 & & & 352.13 & $1,110.63$ \\
\hline
\end{tabular}

${ }^{\text {a }}$ The colors of the cells indicate equivalent output by the conventional methods versus SAM

$H i C$ healthcare insurance companies, $M o F$ ministry of finance, $M o H$ ministry of health, $R V$ rotavirus, $S A M$ Social Accounting Matrix

framework (lower part of the table). It provides additional details regarding the impact of RV vaccination on revenues of each economic agent. The reduction in direct medical costs due to RV vaccination is the same as for conventional methods and is shown as a monetary transfer between $\mathrm{HiC}$ and $\mathrm{MoH}$ (again, the same color codes are used for the cells in the upper and lower part of the table). Both households and firms see their revenues increased thanks to the improved labor input, which translates into higher tax revenues to the MoF. In addition, the MoF receives taxes from the vaccine manufacturer. These gains are partially offset by vaccine costs, which are paid by the $\mathrm{MoH}$ (assuming a $5 \%$ rebate).

The net savings (difference between revenues and vaccine costs) is positive for all methods, except for the net income method (Table 5). Thus, in general, vaccination costs are compensated by higher revenues, thanks to a reduction in work absenteeism. To what extent investment into RV prevention is advantageous for the economy can be assessed through the ROI; that is, the ratio between the net cost savings (total direct and indirect non-medical costs minus vaccine costs) and the vaccine costs (the investment). With conventional methods, the ROI is positive for all methods, except for the net income method. Among the conventional methods, the gross income method leads to the highest ROI with values of 1.241 and 1.221 , respectively. The SAM approach yields a higher estimate for ROI (1.33).

\subsection{Sensitivity Analyses}

In deterministic sensitivity analyses, total number of RV events, lost productivity, reimbursement rate of employees, and vaccine efficacy appear to have the largest impact on the estimated ROI following the conventional methods (Fig. 1). With the modified SAM approach, gross income is the single most important variable. Changing this parameter to estimated extreme values leads to higher variability in the ROI compared with the conventional methods. Changes in gross income impact several economic agents (households, firms, and $\mathrm{MoF}$ ), which might explain why ROI is particularly sensitive to this variable following the SAM approach.

In general, methods with a broader perspective such as SAM and the gross income method are more sensitive to variations in key parameters, while more focused approaches, such as the net income method, show small changes in the ROI in the one-way sensitivity analysis and in their distributions. This is shown in the PSA results: the broadest distribution of estimated ROI values is observed with the SAM approach, while the net income and adjusted gross income methods exhibit narrow distributions (Fig. 2). Despite this high variability, $\mathrm{ROI}$ is positive for the majority of the simulations, meaning that there is a high probability of gaining money when investing in RV vaccination, except if a narrow focus on net income only is considered. 
Table 5 Difference in direct and indirect non-medical costs at the population level with and without RV UMV

\begin{tabular}{|c|c|c|c|c|c|c|c|c|}
\hline \multicolumn{9}{|c|}{ Conventional Methods } \\
\hline Cost Type & \multicolumn{2}{|c|}{ Direct } & \multicolumn{6}{|c|}{ Indirect } \\
\hline Method & \multicolumn{2}{|c|}{ Medical cost } & \multicolumn{2}{|c|}{ Gross income } & \multicolumn{3}{|c|}{ Adjusted gross income } & Net income \\
\hline No vaccine $(€)$ & \multicolumn{2}{|c|}{$9,891,613$} & \multicolumn{2}{|c|}{$59,208,769$} & \multicolumn{3}{|c|}{$22,489,204$} & $13,302,364$ \\
\hline UMV (€) & \multicolumn{2}{|c|}{$1,892,925$} & \multicolumn{2}{|c|}{$24,571,639$} & \multicolumn{3}{|c|}{$9,333,020$} & $5,520,481$ \\
\hline Cost savings $(€)^{\mathbf{a}}$ & \multicolumn{2}{|c|}{ 7,998,688 } & \multicolumn{2}{|c|}{$\mathbf{3 4 , 6 3 7 , 1 3 0}$} & \multicolumn{3}{|c|}{$13,156,184$} & $7,781,883$ \\
\hline Total cost-offset $(€)^{b}$ & & & \multicolumn{2}{|c|}{$42,635,818$} & \multicolumn{3}{|c|}{$21,154,872$} & $15,780,571$ \\
\hline Net savings $(€)^{\mathrm{c}}$ & & & \multicolumn{2}{|c|}{$23,441,418$} & \multicolumn{3}{|c|}{$1,960,472$} & $-3,413,829$ \\
\hline $\mathrm{ROI}^{\mathrm{d}}$ & & & \multicolumn{2}{|c|}{1.221} & \multicolumn{2}{|r|}{0.102} & & -0.178 \\
\hline \multicolumn{9}{|c|}{ SAM Method: Cost (€) Savings Due to RV Vaccination ${ }^{\text {a }}$} \\
\hline & Household & & & MoF & МoH & HiC & $\begin{array}{c}\text { Vaccine } \\
\text { Producer }\end{array}$ & Revenues \\
\hline Household & & & & & & & & $13,156,184$ \\
\hline Firms & $5,836,412$ & & & & & & & $5,836,412$ \\
\hline MoF & $6,599,948$ & & & & & & 959,720 & $14,561,289$ \\
\hline MoH & & & & & & $-7,998,688$ & & $-7,998,688$ \\
\hline \multicolumn{9}{|l|}{ HiC } \\
\hline Vaccine Producer & & & & & $19,194,400$ & & & $19,194,400$ \\
\hline Expenditures & $12,436,360$ & & 305 & & $19,194,400$ & $-7,998,688$ & 959,720 & $44,749,597$ \\
\hline Net savings $(€)^{\mathrm{c}}$ & & & & & & & & $25,555,197$ \\
\hline ROI $^{d}$ & & & & & & & & 1.33 \\
\hline
\end{tabular}

${ }^{a}$ Cost savings are calculated as the difference between costs with no RV vaccination and costs with RV vaccination.

${ }^{\mathrm{b}}$ Total cost-offsets are calculated as the sum of direct and indirect cost savings

c Net savings are calculated as Total cost-offset - Total vaccine cost in case of conventional methods and as Expenditures - Total vaccine cost in case of SAM method

d ROIs are calculated as Net savings / Total vaccine cost

$\mathrm{HiC}$ healthcare insurance companies, $\mathrm{MoF}$ ministry of finance, $\mathrm{MoH}$ ministry of health, $R V$ rotavirus, $U M V$ universal mass vaccination

\section{Discussion}

In this study, we estimated the difference in indirect nonmedical costs due to RV events in the absence or presence of vaccination in the Netherlands using different perspectives and methods. The net savings and the ROI obtained were calculated for each approach and compared with a new method using a modified SAM framework. Indirect nonmedical cost estimates of RV events are in the same order of magnitude or larger than the direct medical costs, except for the net income method, which yielded a much lower estimate. Indirect non-medical cost estimates obtained with the SAM method were towards the higher end of values. The large range in the estimates illustrates the importance of the perspective selected and emphasizes the difficulty in results interpretation for decision making. Many authorities across the world question the sources, methodology, and interpretation of data calculated from a societal perspective because of the many uncertainties surrounding those indirect cost estimates $[1,15]$. Under such circumstances, clear definitions and principles on how to measure it are warranted.
Health technology evaluations typically work with four cost baskets: medical healthcare cost (prevention, treatment, hospitalization, medical visits, tests); non-medical health and healthcare-related cost (transport, specific food, and support); medical infrastructural cost (building, head count, administration); and non-medical work/activity impacted cost (work reduction) [39]. While we can easily quantify the first three cost types, the last item poses problems and its definition remains vague. We can quantify the number of disease events and the days being absent from work [40], however analysts lack clear guidance on how to translate this number into a monetary value relevant to decision makers.

Broadly speaking, several economic stakeholders could be affected by the health condition of a population (individual, household, employer, insurance company or government). Current methodological approaches use a general denominator across all these economic stakeholders, that is, production and production loss. Different surrogate markers for production exist for different perspectives in isolation, but which one best approximates our overall economic functioning remains elusive. It is generally agreed 
SAM method

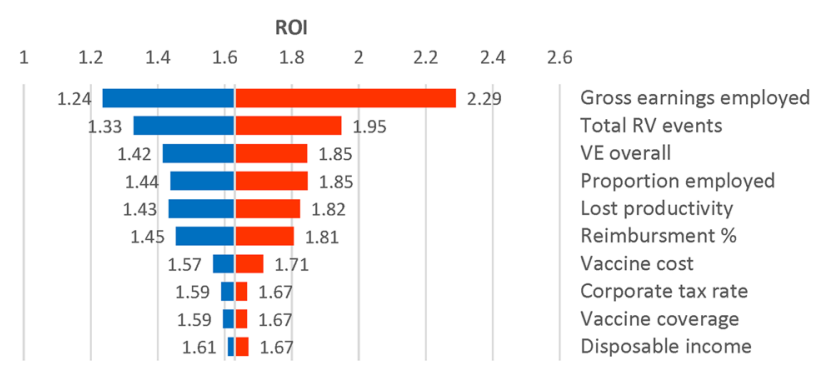

Adjusted gross income method

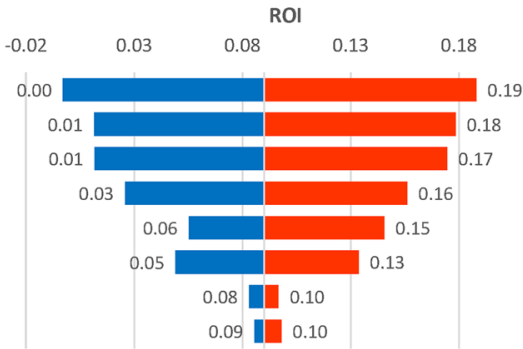

Gross income method

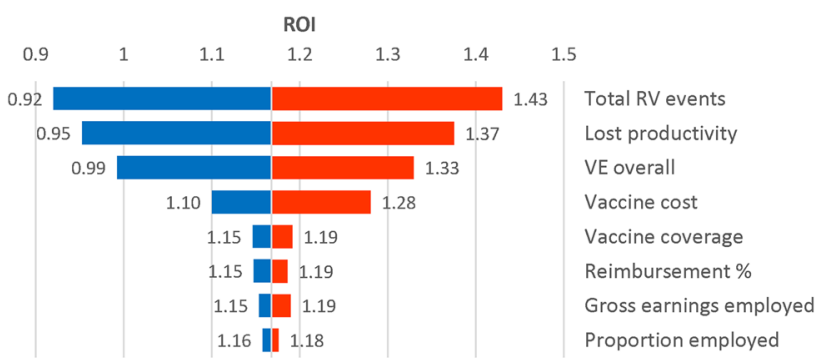

Net income method

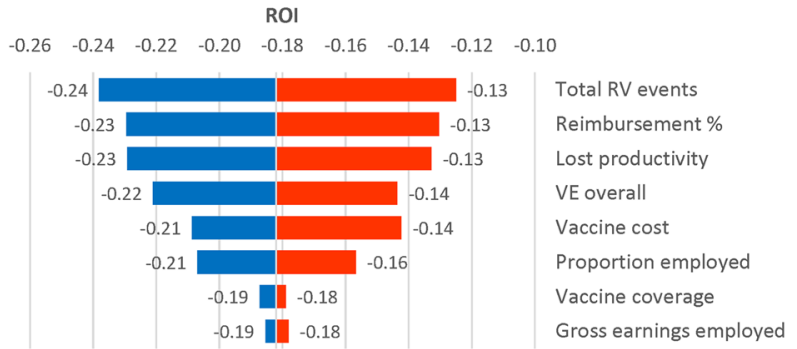

Fig. 1 Deterministic sensitivity analyses to assess impact of key parameters on ROI with different methods. Prop proportion, ROI return on investment, $R V$ rotavirus, $S A M$ social accounting matrix, Vac_cov vaccination coverage, $V E$ vaccine efficacy

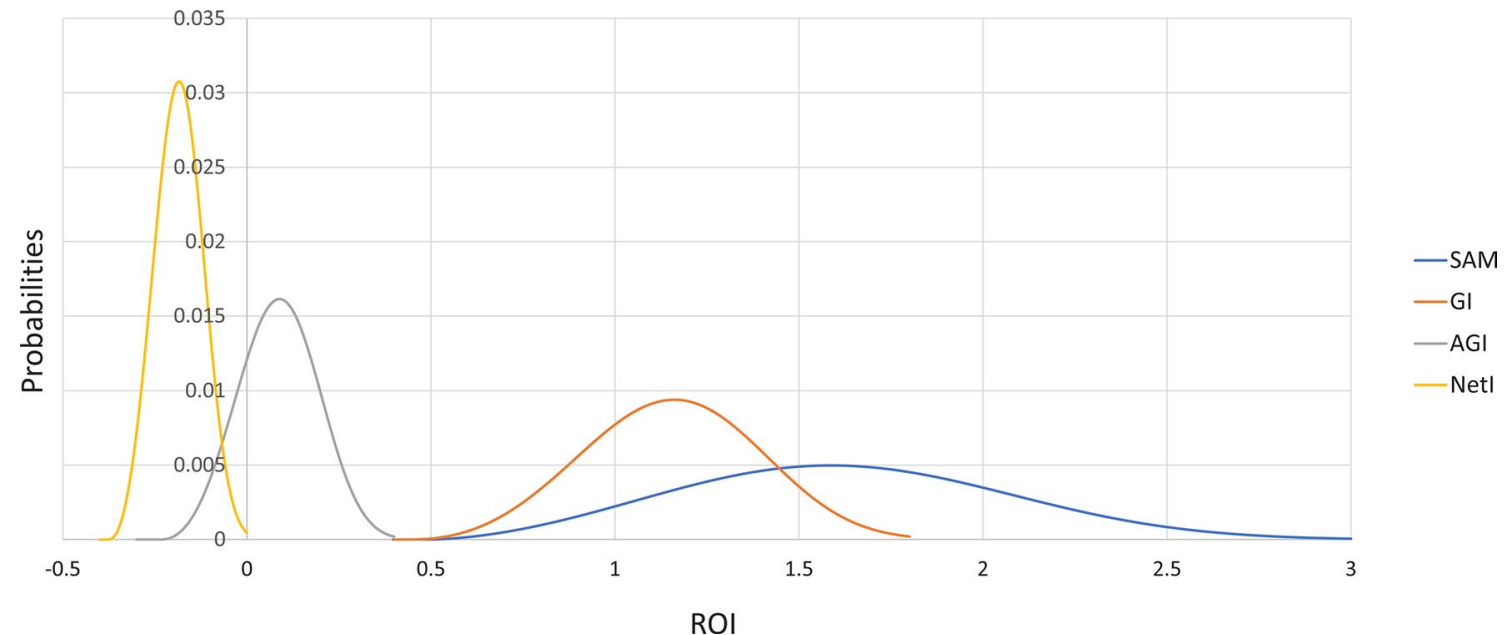

Fig. 2 PSA to assess impact of key parameters on the distribution of ROI estimates with different methods. AGI adjusted gross income, GI gross income, NetI net income, PSA probabilistic sensitivity analysis, ROI return on investment, SAM social accounting matrix

upon that indirect non-medical costs are important $[15,41$, 42]. The social security system has been developed on that need, based on the solidarity principle that sick people need medical attention and continued income during the period of illness [43]. These indirect non-medical costs are generally funded through social security and can be vast compared with direct medical costs, but we rarely consider them in health economic evaluations. Rather, we use the more abstract concept of production loss for historical reasons or ease of use. Meanwhile, other economic disciplines, especially the financial world, are exposed to similar situations where a particular event leads to downstream effects outside of the economy where the initial event happened. To follow the ramifications and financial consequences over time, SAMs, in addition to other overall economic models such as CGEs, were developed [44].

We applied an adaptation of the same technique to evaluating the economic impact of RV vaccination in the 
Netherlands at the societal level, focusing on indirect nonmedical costs. Compared with the conventional methods, the modified SAM approach includes monetary gains and losses due to RV intervention for all economic stakeholders simultaneously. Many of the indirect non-medical cost measures calculated by conventional methods are also included in the SAM approach, but the SAM discloses additional information about which stakeholders are involved with the direction of money transfers. One most revealing item is the specific tax payment gained by the MoF through better prevention. This is not disclosed using the conventional methods of assessments. This is critical when comparing treatment versus prevention, as shown in the example of RV vaccination, because indirect non-medical costs are in the same order of magnitude as direct medical costs [45]. The observed economic gain is more important with the SAM approach, because all money-flow perspectives are factored in.

Because of the interconnectivity between economic agents through monetary transactions, changes in input parameters may impact multiple elements in the SAM framework simultaneously. This translates into large variability in the total cost estimates, more than typically seen with the conventional methods. In the PSA, the modified SAM exhibits the widest distribution in ROI values, though ROI remains positive in all simulations. One-way sensitivity analyses highlight that the ROI was mostly affected by the gross income in the SAM approach, while conventional methods are most sensitive to the total number of RV events, lost productivity, vaccine efficacy, and reimbursement rate of employees. SAMs may therefore provide a more realistic picture regarding the uncertainty around cost estimates because they evaluate all the interactions between the economic stakeholders.

One may question why we should use SAM assessment in healthcare. SAM is an instrument mainly developed to better assess changes in policy on tax income and payment for the overall economy of a specific place, over a fixed evaluation period. Should the healthcare budget, being around 10-15\% of the annual governmental budget expenditures, also comply with the rules of SAM evaluations? Would it be more helpful for decision makers to realize that prevention helps the economy overall and that employers could benefit as well in getting this prevention in place, as shown here? We are not advocating that SAM should systematically be applied within healthcare per se, but for some critical diseases such as infectious diseases with good preventative options like vaccination or more frequent chronic diseases for which management options prevent severe negative outcomes, a SAM evaluation can be very supportive in better decision making at all levels.

Limitations of the SAM approach versus conventional methods include the use of multiple data and data sources at different levels of the economy, ranging from household to private companies/firms, insurance providers, and the healthcare sector. Information to populate SAM models may be more accessible in countries with a fully developed health insurance landscape. At the same time, these countries may benefit the most from the SAM approach, which provides a more complete and transparent picture of the effect a new intervention has on the overall economy. Today, there is no reference for the use of SAMs in health technology assessments and this might constitute a significant hurdle in adopting this method. By directly comparing the conventional methods and results with the SAM approach, we aim to increase the reliability, validity, and awareness of the SAM method in the pharmacoeconomic community. Meanwhile, we should keep in mind that SAM evaluations are not new but have been widely used in the financial and public world $[18,44]$. In addition, because the SAM method has not previously been applied to the healthcare sector, there is no precedent in what constitutes an acceptable ROI in that domain. The SAM method yields a higher estimate of indirect non-medical costs than the other methods; this difference is attributed to the fact that in the SAM approach all economic ramifications of an intervention and financial relationships are included. Therefore, future research should be directed towards defining acceptable values for ROI of a new intervention from a societal perspective and careful consideration should be given to the choice of method for calculating changes in the labor input function.

\section{Conclusion}

A modified SAM approach combines all economic agents impacted by a disease and/or a disease intervention into a single framework. It provides a complete and transparent picture of the impact a new intervention can have on the economy, and therefore might be a suitable tool to investigate direct and indirect non-medical costs from a societal perspective. In the case of RV vaccination, direct and indirect non-medical costs estimated with the SAM approach are in favor of vaccination in the Netherlands. The SAM method provides more details regarding the redistribution of money flow in the presence of RV vaccination and this level of detail might improve confidence in the results and strengthen decisions taken by policy makers. However, it does not mean that SAM evaluations should replace any other economic assessment normally done in healthcare focusing on health gain expressed as QALYs. Our approach suggests how to better estimate indirect costs with available evaluation methods that could be readily applied in healthcare, providing transparency to different decision makers and creating a better dialogue between stakeholders. 
Acknowledgements Authors would like to thank Business \& Decision Life Sciences platform for editorial assistance and manuscript coordination, on behalf of GSK. Amandine Radziejwoski coordinated manuscript development and editorial support and Katrin Spiegel provided medical writing support.

\section{Declarations}

Funding GlaxoSmithKline Biologicals S.A. funded this study (GSK study identifier: HO-18-19703) and all costs related to the development and publication of this manuscript. Q. Leclerc reports a grant from UK Medical Research Council during the conduct of the study (grant no. MR/N013638/1).

Conflicts of interest/Competing interests B Standaert was an employee of the GSK group of companies during the study conduct and holds stock in the GSK group of companies. C. Sauboin was an employee of the GSK group of companies during the study conduct. M. Connolly declares he has consulted for the GSK group of companies in the past and received no financial compensation for the development of this manuscript. Q. Leclerc has no financial conflicts of interests to disclose. Authors declare no other financial and non-financial relationships and activities.

Availability of data and material (data transparency) Data and material may be found in Kotsopoulos et al., 2019 [22].

Code availability (software application or custom code) MS Excel and @ Risk Palisade, 8.0.

Authors' contributions All authors participated in the design or implementation or analysis and interpretation of the study; all authors participated in the development of this manuscript. All authors had full access to the data and gave final approval before submission.

Trademarks Rotarix is a trademark owned by or licensed to the GSK group of companies. Rotateq is a trademark owned by or licensed to Merck \& Co, USA.

Open Access This article is licensed under a Creative Commons Attribution-NonCommercial 4.0 International License, which permits any non-commercial use, sharing, adaptation, distribution and reproduction in any medium or format, as long as you give appropriate credit to the original author(s) and the source, provide a link to the Creative Commons licence, and indicate if changes were made. The images or other third party material in this article are included in the article's Creative Commons licence, unless indicated otherwise in a credit line to the material. If material is not included in the article's Creative Commons licence and your intended use is not permitted by statutory regulation or exceeds the permitted use, you will need to obtain permission directly from the copyright holder. To view a copy of this licence, visit http://creativecommons.org/licenses/by-nc/4.0/.

\section{References}

1. Drummond MF, Sculpher MJ, Claxton K, Stoddart GL, Torrance GW. Methods for the economic evaluation of health care programmes. 4th ed. Oxford: Oxford University Press; 2015.

2. Neumann PJ, Sanders GD, Russell LB, Siegel JE, Ganiats TG. Cost-effectiveness in health and medicine. Oxford: Oxford University Press; 2017.
3. Culyer AJ. Cost-effectiveness thresholds in health care: a bookshelf guide to their meaning and use. Health Econ Policy Law. 2016;11(4):415-31.

4. Cleemput I, Neyt M, Thiry N, De Laet C, Leys N. Using threshold values for cost per quality-adjusted life-year gained in health care decisions. Int J Technol Assess Health Care. 2011;27(1):5.

5. Garrison LP Jr, Pauly MV, Willke RJ, Neumann PJ. An overview of value, perspective, and decision context-a health economics approach: an ISPOR special task force report [2]. Value Health. 2018;21(2):124-30.

6. Garrison LP, Jr., Mansley EC, Abbott TA, 3rd, Bresnahan BW, Hay JW, Smeeding J. Good research practices for measuring drug costs in cost-effectiveness analyses: a societal perspective: the ISPOR Drug Cost Task Force report-Part II. Value Health. 2010;13(1):8-13.

7. Schofield D, Shrestha R, Percival R, Passey M, Callander E, Kelly $\mathrm{S}$. The personal and national costs of CVD: impacts on income, taxes, government support payments and GDP due to lost labour force participation. Int J Cardiol. 2013;166(1):68-71.

8. Polimeni JM, Vichansavakul K, Iorgulescu RI, Chandrasekara R. Why perspective matters in health outcomes research analyses. Int Bus Econ Res J. 2013;12(11):1503-12.

9. Walker S, Griffin S, Asaria M, Tsuchiya A, Sculpher M. Striving for a societal perspective: a framework for economic evaluations when costs and effects fall on multiple sectors and decision makers. Appl Health Econ Health Policy. 2019;17(5):577-90.

10. Sherman EJ, Pfister DG, Ruchlin HS, Rubin DM, Radzyner MH, Kelleher GH, et al. The Collection of Indirect and Nonmedical Direct Costs (COIN) form: a new tool for collecting the invisible costs of androgen independent prostate carcinoma. Cancer. 2001;91(4):841-53.

11. Krol M, Papenburg J, Tan SS, Brouwer W, Hakkaart L. A noticeable difference? Productivity costs related to paid and unpaid work in economic evaluations on expensive drugs. Eur J Health Econ. 2016;17(4):391-402.

12. Kotsopoulos N, Connolly M. Is the gap between micro- and macroeconomic assessments in health care well understood? The case of vaccination and potential remedies. J Mark Access Health Policy. 2014;2(10):23897.

13. Mitchell RJ, Bates P. Measuring health-related productivity loss. Popul Health Manag. 2011;14(2):93-8.

14. Scholz S, Koerber F, Meszaros K, Fassbender RM, Ultsch B, Welte RR, et al. The cost-of-illness for invasive meningococcal disease caused by serogroup B Neisseria meningitidis (MenB) in Germany. Vaccine. 2019;37(12):1692-701.

15. Ratcliffe $\mathrm{J}$. The measurment of indirect costs and benefits in health care evaluation: a critical review. Project Appraisal. 1995;10(1):13-8.

16. Round J. Social accounting matrices and SAM-based multiplier analysis. the impact of economic policies on poverty and income distribution: evaluation techniques and tools. 2003:301-20.

17. Mainar-Causapé AJ, Ferrari E, McDonald S. Social Accounting Matrices: basic aspects and main steps for estimation. 2018. [Last update: 2018, cited: September 1, 2020]; 10.2760/010600.

18. Breisinger C, Thurlow J, Duncan M. A 2005 social accounting matrix (SAM) for Ghana. 2007. [Last update: October 2007, cited: March 26, 2020]; https://www.gtap.agecon.purdue.edu/resources/ download/4257.pdf.

19. World Health Organization. WHO guide to identifying the economic consequences of disease and injury. 2009. [Last update: 2009, cited: March 26, 2020]; https://www.who.int/choice/publi cations/d_economic_impact_guide.pdf.

20. Bruijning-Verhagen $\mathrm{P}$, van Dongen JAP, Verberk JDM, Pijnacker $\mathrm{R}$, van Gaalen RD, Klinkenberg D, et al. Updated cost-effectiveness and risk-benefit analysis of two infant rotavirus vaccination 
strategies in a high-income, low-endemic setting. BMC Med. 2018;16(1):168.

21. Rozenbaum MH, Mangen MJ, Giaquinto C, Wilschut JC, Hak E, Postma MJ, et al. Cost-effectiveness of rotavirus vaccination in the Netherlands; the results of a consensus model. BMC Public Health. 2011;10(11):462.

22. Kotsopoulos N, Haitsma G, Connolly MP, Standaert B. Estimating the money flow in the economy attributed to rotavirus disease and vaccination in the Netherlands using a Social Accounting Matrix (SAM) framework. Expert Rev Pharmacoecon Outcomes Res. 2019;22:1-10.

23. Poelaert D, Pereira P, Gardner R, Standaert B, Benninghoff B. A review of recommendations for rotavirus vaccination in Europe: arguments for change. Vaccine. 2018;36(17):2243-53.

24. Karafillakis E, Hassounah S, Atchison C. Effectiveness and impact of rotavirus vaccines in Europe, 2006-2014. Vaccine. 2015;33(18):2097-107.

25. Rotarix. Summary of Product Characteristics. GlaxoSmithKline Biologicals s.a. 2020. [Last update: 14 January 2016, cited: 02 September 2020]; https://www.ema.europa.eu/en/documents/ product-information/rotarix-epar-product-information_en.pdf.

26. Rotateq. Summary of Product Characteristics. MSD Vaccins. 2020. [Last update: 18 May 2011, cited: 02 September 2020]; https://www.ema.europa.eu/en/documents/product-information/ rotateq-epar-product-information_en.pdf.

27. Goossens LM, Standaert B, Hartwig N, Hovels AM, Al MJ. The cost-utility of rotavirus vaccination with Rotarix (RIX4414) in the Netherlands. Vaccine. 2008;26(8):1118-27.

28. Krol M, Brouwer W, Rutten F. Productivity costs in economic evaluations: past, present, future. Pharmacoeconomics. 2013;31(7):537-49.

29. Weisbrod B. The valuation of human capital. J Polit Econ. 1961;69(5):425-36.

30. Cothern L. Gross income vs net income: what's the difference? 2019. [Last update: September 25, 2020, cited: June 15, 2020]; https://www.creditkarma.com/advice/i/gross-vs-net-income/.

31. Standaert B, Van De Mieroop E, Nelen V. Exploring the potential impact of rotavirus vaccination on work absenteeism among female administrative personnel of the City of Antwerp through a retrospective database analysis. BMJ Open. 2015;5:e007453.

32. De Rijksoverheid (Internet). Rijksoverheid, Home, Onderwepren, Zorgverlof, documenten. Rijksoverheid. 2019. [Last update: June 24, 2019, cited: June 8, 2020]; https://www.rijksoverheid.nl/onder werpen/zorgverlof/documenten.

33. Leadership group (LEG) on Social Accounting Matrices under the co-ordination of Statistics Netherlands. Handbook on social accounting matrices and labour accounts. European Commission. 2003. [Last update: April 30, 2003, cited: June 8, 2020]; https://www.google.com/url?sa $=$ t\&rct $=j \& q=\&$ esrc $=$ s\&sourc $\mathrm{e}=$ web \&cd $=\& \mathrm{cad}=$ rja\&uact $=8 \&$ ved $=2$ ahUKEwjz5_PhpvLp AhVCjqQKHWcNCoEQFjABegQIAxAC\&url=https\%3A\%2 F\%2Fwww.cbs.n1\%2F-\%2Fmedia\%2Fimported $\% 2$ Fonze $\% 252$ 0diensten $\% 2$ Fmethoden $\% 2$ Fdataverzameling $\% 2$ Faanvullende $\% 2520$ onderzoeksbeschrijvingen $\% 2$ Fdocuments $\% 2 \mathrm{~F} 2011 \% 2 \mathrm{~F}$ 38\%2F2011-social-accounting-matrices-and-labour-accounts. pdf\%3Fla\%3Dnl-nl\&usg=AOvVaw3Db_g-Onnpo_Bt8YPdF7vj.

34. Stone R. Measurement of national income and the construction of social accounts (Geneva, United Nations). 1947.

35. Pyatt G, Thorbecke E. Planning techniques for a better future; a summary of a research project on planning for growth, redistribution and employment. Geneva (Switzerland): Geneva (Switzerland) ILO; 1976

36. Boulding K. The economics of the coming spaceship earth. In: Jarrett H, editor. Environmental quality in a growing economy. Baltimore: Resources for the Future/Johns Hopkins University Press; 1966.
37. Connolly MP, Kotsopoulos N, Postma MJ, Bhatt A. The Fiscal consequences attributed to changes in morbidity and mortality linked to investments in health care: a government perspective analytic framework. Value Health. 2017;20(2):273-7.

38. Masters R, Anwar E, Collins B, Cookson R, Capewell S. Return on investment of public health interventions: a systematic review. J Epidemiol Community Health. 2017;71(8):827-34.

39. Gardiner C, Ingleton C, Ryan T, Ward S, Gott M. What cost components are relevant for economic evaluations of palliative care, and what approaches are used to measure these costs? a systematic review. Palliat Med. 2017;31(4):323-37.

40. Barnighausen T, Berkley S, Bhutta ZA, Bishai DM, Black MM, Bloom DE, et al. Reassessing the value of vaccines. Lancet Glob Health. 2014;2(5):e251-2.

41. OECD. Coronavirus: the world economy at risk. OECD Interim Economic Outlook. 2020. [Last update: June 2020, cited: March 3, 2020]; oecd.org/economic-outlook.

42. Pike J, Grosse SD. Friction cost estimates of productivity costs in cost-of-illness studies in comparison with human capital estimates: a review. Appl Health Econ Health Policy. 2018;16(6):765-78.

43. Barr N. Economics of the welfare state. 6th ed. Oxford: Oxford University Press; 2012.

44. Chen W, Chen C, Chen F, Liu C. The impact of the taipei port container terminal on the northern region of Taiwan: a compuatble general equilibrium model. J Mar Sci Technol. 2011;19(2):120-6.

45. Aballea S, Millier A, Quilici S, Caroll S, Petrou S, Toumi M. A critical literature review of health economic evaluations of rotavirus vaccination. Hum Vaccin Immunother. 2013;9(6):1272-88.

46. ZorgInstituut Nederland. Farmaco-Economisch rapport voor humaan rotavirus, monovalent (Rotarix ${ }^{\circledR}$ ) als actieve immunisatie, bij zuigelingen van 6 tot 24 weken, ter voorkoming van gastroenteritis veroorzaakt door een rotavirusinfectie. 2017. [20 july 2017, cited: June 8, 2020].

47. Central Bureau of Statistics. Werkzame beroepsbevolking; gemiddeld inkomen. 2018. [Last update: February 13, 2020, cited: August 16, 2018]; https://opendata.cbs.n1/statline/\#/CBS/nl/datas et/83686NED/table?ts=1519746440001.

48. Belastingdienst. Inkomstenbelasting; Heffingskortingen, boxen en tarieven; Boxen en tarieven; Overzicht tarieven en schijven. 2018. [Last update: 2018, cited: August 16, 2018]; https://www. belastingdienst.nl/wps/wcm/connect/bldcontentnl/belastingd ienst/prive/inkomstenbelasting/heffingskortingen_boxen_tarie ven/boxen_en_tarieven/overzicht_tarieven_en_schijven/u-hebtin-2018-de-aow-leeftijd-nog-niet-bereikt.

49. Rijksoverheid. Rijksoverheid, Home, Onderwerpen, Zorgverlof, Documenten. 2018. [Last update: September 28, 2020, cited: August 16, 2018]; https://www.rijksoverheid.nl/onderwerpen/ zorgverlof/documenten.

50. Central Bureau of Statistics. Inkomensverdeling van huishoudens; nr, 2005-2014. 2018. [Last update: August 22, 2017, cited: August 16, 2018]; https://opendata.cbs.nl/statline/\#/CBS/nl/dataset/82959 NED/table?ts $=1532525633247$.

51. OECD. Consumption Tax Trends. 2016. [Last update: 2020, cited: August 16, 2018]; https://www.oecd-ilibrary.org/content/publi cation/ctt-2016-en.

52. Central Bureau of Statistics. National accounts of the Netherlands. The Hague: Statistics Netherlands; 2016.

53. Belastingdienst. Winst, Vennootschapsbelasting, Tarieven vennootschapsbelasting. 2018. [Last update: 2020, cited: August 16, 2018]; https://www.belastingdienst.nl/wps/wcm/connect/bldco ntentnl/belastingdienst/zakelijk/winst/vennootschapsbelasting/ tarieven_vennootschapsbelasting. 